\title{
DENSITY AND VISCOSITY EQUATION OF BLEND OIL
}

\author{
Renata Rădulescu ${ }^{1}$, Timur Chiș ${ }^{2 *}$,
}

${ }^{1}$ Oil and Gas University of Ploiesti, Petroleum and Gas Engineering Faculty, Petroleum and Gas Department, B-dul București, Ploiesti, Romania

${ }^{2}$ Ovidius University Constanta, Applied Science Engineering Faculty, Chemical and Chemical Engineering Department, B-dul Mamaia, Constanta, Romania

e-mail: timur.chis@gmail.com,

\section{DOI: 10.51865/JPGT.2021.01.09}

\begin{abstract}
Extracted oils and gases have different physical and chemical properties, depending on oil structures.

Thus, it is beneficial to create mixtures of oils by combining cheaper crude oils with variants that have better properties (Brent type).

This will result, in a reduced cost of acquisition.

Mixing crude oil (obtaining blend crude oil) is a process in constant development, so that new ways for improving crude oil properties can be surfaced and to create new ways for transport and storage with lower costs. As an example, by mixing crude oil we can ensure viscosities and freezing conditions for certain transport systems.

The aim of this paper is to present the techniques for mixing crude oil, the study of technologies, equipment needed for it and the numerical models for obtaining optimal mixing rates.
\end{abstract}

Keywords: oil blending, viscosity, density, mathematical modelling.

\section{INTRODUCTION}

In the conditions of increasing price of crude oil in the international market and constant sales prices of petroleum products at the same level, any refinery ensures the efficiency of processing by:

a. reduction of the profit margin on processing;

b. providing cheaper crude oil for processing;

c. ensuring similar blend crude oils with the same qualities as the ones that were the basis of the refinery design.

Under these conditions, the refineries in Romania process the following types of crude oil during this period: 
a. a mixture of selected oil type paraffinic and selected type asphaltenic is provided, in the Brazi refinery,

b. a mixture of crude oil without sulfur and Rebco crude oil (Russia) is provided in the Teleagen refinery,

c. a mixture of Kazakhstan (CPC) and Rebco (Russia) crude oil is provided at the Midia refinery.

As the refineries can be seen:

a. they changed their oil supplier after 1990 ,

b. they changed the type of crude oil they processed.

This is why the need to deliver blend crude oil is dictated by:

a. ensuring a constant volume of oil with strict conditions regarding the refinery products property (in order to obtain maximum quality finished products within the refinery), considering that during the production of the field (which was the basis of the refinery design) it decreases due to the attrition of the deposit;

b. ensuring a crude oil with better qualities and therefore higher selling prices of final products;

c. obtaining quality final products (considering that fuel oil has a decreasing price and sales trend).

\section{THE CURRENT STATE OF RESEARCH IN THE FIELD OF OBTAINING BLEND CRUDE OIL}

The first research in the field of obtaining blend type crude oil was carried out in ancient China, when the extracted crude oil was mixed for their use as a fuel needed to heat homes or especially their lighting. The Phoenicians also used crude oil mixtures to make the bitumen needed to repair transport ships.

The mixing of crude oil is presented by the Catholic Church as the resin made by witches in a boiler [1].

In Romania, early research studies regarding the mixing of crude oils and petroleum products were carried out within the Chemical Analysis Laboratory at CHIMPEX CONSTANT,A, Petroleum Products Conditioning Enterprise by Jenicu Nicolau [2] in 1970 .

The studies purpose was to establish:

a. optimal recipes for mixtures of diesel and fuel oil, to sale it as naval fuel,

b. optimal recipes of some crude oil mixtures, in order to ensure the transport conditions through pipes.

The final result of the research consisted in assimilating the mixing conditions of the oils (using the Henri Maurin [3] indices) to the production of blend crude oils (with the remark that before ensuring the mixing rates, laboratory tests should be performed).

Also in the work "Mathematical programming in the oil industry", Mr. Gh. I. Barbatu [4] presented a linear mathematical model for ensuring the oil mixtures necessary for processing. 
In this model we tried to linearize the oil mixtures depending only on the price and the processing conditions, and less on the physical properties characteristics of the components.

The research was resumed by Timur Chiș $[5,6]$, by trying to find a mathematical model to ensure the behavior of crude oil mixtures, depending on the physical and chemical properties (density, viscosity and freezing point).

In the laboratory studies, undertaken and in the published articles the following were presented:

a. behavior of the viscosity of Romanian crude oils, following their mixing;

b. effect of additives on crude oil mixtures;

c. what is the optimal mathematical model in solving crude oil mixtures.

In the world literature, crude oil mixtures, are studied to ensure their optimization in creating blends as cost-effective as possible $[7,8]$.

In the article "A Novel Scheduling Strategy for Crude Oil Blending" [9], a numerical model is presented that aims at optimizing the mixtures starting from the flow control of the various components of the resulting blend. Following the application of this model, a useful computer application can be made in the production of blend crude oil, which takes into account only the crude oil flow and its price (in order to create a more profitable blend). At the same time, the final result is the influence of mixing on the distillation curves.

\section{MATERIALS AND METHODS}

In order to see the behavior of the physical parameters of the compounds during the realization of the oil mixtures, a set of laboratory tests was performed on a mixture of two crude oils.

The study of density and viscosity tried to:

a. Determine the variation of these properties with the mixing ratio (Table 1, Table 2,)

b. Verify the results against existing numerical models (Table 3, Table 4, Table 5)

c. Creation of a new model of numerical simulation (Table 6, Table 7, Table 8)

Viscosity was determined according to ASTM D1665 - 98 (2009) [10] (Error of measurement is maximum $0,1 \%$ ).

The density was determined according to ASTM D1298-99 (2005) [11] (Error of measurement is maximum $0,1 \%$ ).

The experiment consisted in mixing of two crude and observation of influence of oil ratios on viscosity and density (Table 1).

\section{Density blending calculation}

For mixtures, the density is calculated as a weighted average by volume or mass:

$\rho_{a m}=\frac{\sum_{i=1}^{n} \rho_{i} V_{i}}{\sum_{i=1}^{n} V_{i}}$ or $\rho_{a m}=\frac{\sum_{i=1}^{n} m_{i}}{\sum_{i=1}^{n} \frac{m_{i}}{\rho_{i}}}$ 
Where:

$\rho_{a m}$ is blend density,

$\rho_{i}$ is component blending density,

$V_{i}$ is volume of component blending,

$m_{i}$ is mass of component blending.

Table 1 Properties of oil used (measurement according to the standards)

\begin{tabular}{|c|c|c|}
\hline Properties & $\begin{array}{c}\text { PETROMAR Oil } \\
\text { (Romania) }\end{array}$ & $\begin{array}{c}\text { BASHRA Oil } \\
\text { (Irak) }\end{array}$ \\
\hline Density at $15^{\circ} \mathrm{C}$ & 0,8255 & 0,8702 \\
\hline Viscosity at $20^{\circ} \mathrm{C}$ & $4,66^{\circ} \mathrm{E}$ & $1,88^{\circ} \mathrm{E}$ \\
\hline Freezing Point & $0{ }^{\circ} \mathrm{C}$ & $-23^{\circ} \mathrm{C}$ \\
\hline Sulph contained & $0,2 \%$ & $2,3 \%$ \\
\hline
\end{tabular}

Table 2. Properties of oil blending determined in laboratory (Error of measurement is maximum $0,1 \%$ ).

\begin{tabular}{|c|c|c|c|c|}
\hline $\begin{array}{c}\text { Oil ratio } \\
\text { BASHRA } \\
\mathrm{ml},\end{array}$ & $\begin{array}{c}\text { Oil ratio } \\
\text { PETROMAR } \\
\mathrm{ml},\end{array}$ & $\begin{array}{c}\text { Blend density } \\
\text { measurement }\end{array}$ & $\begin{array}{c}\text { Blend } \\
\text { viscosity (s), } \\
\text { measurement }\end{array}$ & $\begin{array}{c}\text { Blend } \\
\text { viscosity }\left({ }^{\circ} \mathrm{E}\right), \\
\text { measurement }\end{array}$ \\
\hline 200 & 0 & 0.8702 & 96 & 1.881 \\
\hline 190 & 10 & 0.8679 & 99 & 1.941 \\
\hline 180 & 20 & 0.865 & 103 & 2.019 \\
\hline 150 & 50 & 0.8590 & 112 & 2.196 \\
\hline 50 & 150 & 0.8366 & 172 & 3.372 \\
\hline 20 & 180 & 0.829 & 208 & 4.078 \\
\hline 0 & 200 & 0.8255 & 238 & 4.666 \\
\hline
\end{tabular}

Table 3. Final analysis of the density of the oil mixture

\begin{tabular}{|c|c|c|c|}
\hline $\begin{array}{c}\text { Oil ratio } \\
\text { BASHRA } \\
\mathrm{ml},\end{array}$ & $\begin{array}{c}\text { Oil ratio } \\
\text { PETROMAR } \\
\mathrm{ml},\end{array}$ & $\begin{array}{c}\text { Blend density } \\
\text { measurement }\end{array}$ & $\begin{array}{c}\text { Blend density calculated } \\
\text { with the relationship 1 }\end{array}$ \\
\hline 200 & 0 & 0,8702 & 0,8702 \\
\hline 190 & 10 & 0,8679 & 0,8679 \\
\hline 180 & 20 & 0,8657 & 0,8657 \\
\hline 150 & 50 & 0,8590 & 0,8590 \\
\hline 50 & 150 & 0,8366 & 0,8366 \\
\hline 20 & 180 & 0,8299 & 0,8299 \\
\hline 0 & 200 & 0,8255 & 0,8255 \\
\hline
\end{tabular}

Figure 1 shows the results obtained by relation 1 to the laboratory determinations.

An error of $0 \%$ is observed. 


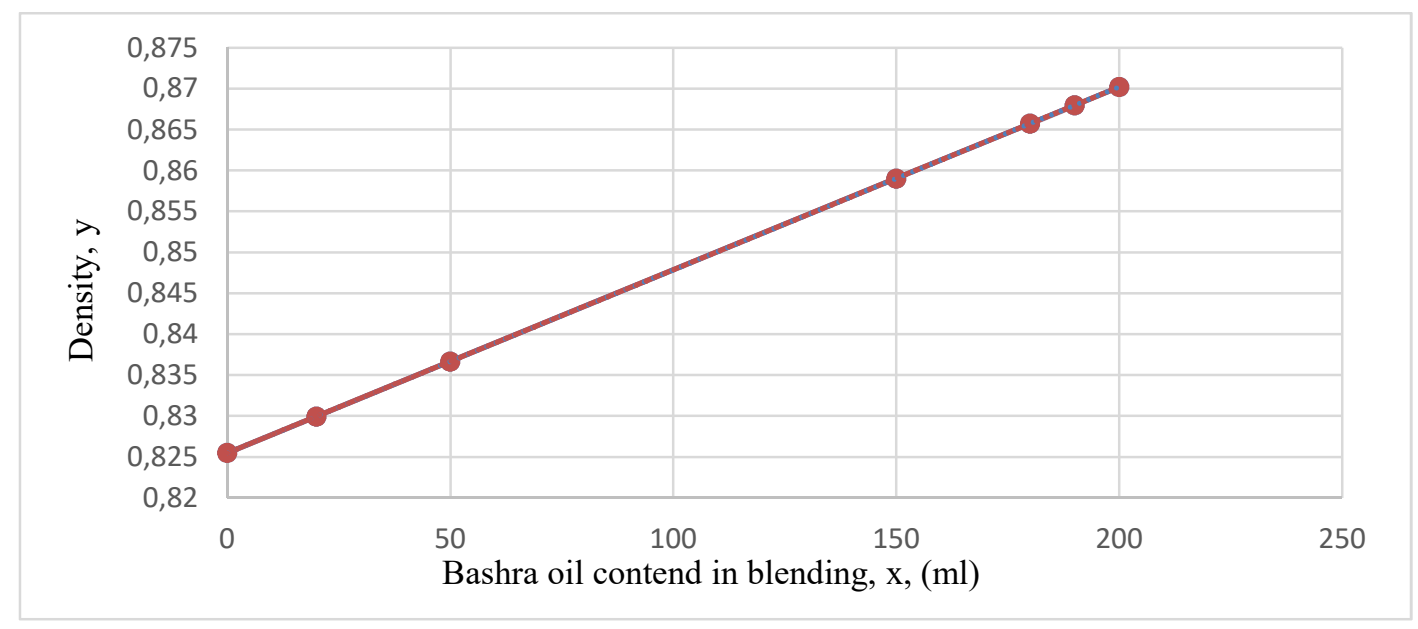

Figure 1. Mixture density determined by physical analysis, as well as the calculation formula determined by numerical regression

\section{Viscosity blending calculation}

To obtain a calculation ratio of the viscosity of crude oil mixtures, in the first phase we used a percentage calculation ratio:

$\gamma_{a m}=\frac{\sum_{i=1}^{n} \gamma_{i} \cdot v_{i}}{\sum_{i=1}^{n} V_{i}}$

Where (2):

$\gamma_{a m}$ is blending viscosity,

$\gamma_{i}$ is viscosity of component blending,

$V_{i}$ is volume of component blending,

In the second part of the research, we calculated the viscosity based on the statistical relation (Figure 2):

$y=-0,0131 x+4,3587$

Where:

$\mathrm{y}$ is viscosity of blend $\left({ }^{\circ} \mathrm{E}\right)$,

$\mathrm{x}$ is ratio of oil Bashra by blending.

In the scientific paper [3], it was possible to define a system for determination the viscosity behavior of oil mixtures, which can also be useful for oil mixtures.

We start from the use of correlation (mixing) indices in the calculation of viscosity.

The equation for calculating the viscosity of the mixture is:

$I H M=\sum_{i=1}^{m} m_{i} \cdot I H M_{i}$

Where:

$I H M_{i}$ is pseudo-property (Henry Maurin Index)

$m_{i}$ is quantity of blending component 
The method of calculating the viscosity of the mixture is as follows:

- the Henri Maurin indices for the two crude oils are determined by table annexed in paper [3],

- mixture indices are determined in the established proportion,

$I A=I A_{\text {OIL_BASHRA }} \cdot \%$ oil_BASHRA $+I_{\text {OIL_PETROMAR }_{-}} \cdot \%$ oil_PETROMAR

- then from the table is determined the viscosity of the mixture by table annexed in paper [3].

Table 4. Viscosity of oil blending determined in laboratory (Error of measurement is maximum $0,1 \%$ ).

\begin{tabular}{|c|c|c|c|}
\hline $\begin{array}{c}\text { Oil ratio } \\
\text { BASHRA } \\
\text { ml, }\end{array}$ & $\begin{array}{c}\text { Oil ratio } \\
\text { PETROMAR } \\
\text { ml, }\end{array}$ & $\begin{array}{c}\text { Blend viscosity (s) } \\
\text { measurement }\end{array}$ & $\begin{array}{c}\text { Viscosity determined } \\
\left({ }^{\circ} \mathrm{E}\right)\end{array}$ \\
\hline 200 & 0 & 96 & 1,8823 \\
\hline 190 & 10 & 99 & 1,9411 \\
\hline 180 & 20 & 103 & 2,0196 \\
\hline 150 & 50 & 112 & 2,1960 \\
\hline 50 & 150 & 172 & 3,3725 \\
\hline 20 & 180 & 208 & 4,0784 \\
\hline 0 & 200 & 238 & 4,6666 \\
\hline
\end{tabular}

Table 5. Viscosity calculated by relationship 2

\begin{tabular}{|c|c|c|c|}
\hline $\begin{array}{c}\text { Viscosity } \\
\text { determined }\left({ }^{\circ} \mathrm{E}\right)\end{array}$ & $\begin{array}{c}\text { Absolute error } \\
\text { (viscosity } \\
2\end{array}$ & $\begin{array}{c}\text { Relative error (\%), } \\
\text { (absolute error } \\
\text { measurement function } \\
\text { by viscosity } \\
\text { determined whit } \\
\text { relationship 2) } \\
\text { determined whit } \\
\text { relationship 2) }\end{array}$ & $\begin{array}{c}\text { Relative error with } \\
\text { percentage } \\
\text { BASHRA ratio, \% }\end{array}$ \\
\hline 1,8823 & 0 & 0 & 0 \\
\hline 2,0215 & $-0,0804$ & $-0,0414$ & $-4,1419$ \\
\hline 2,1607 & $-0,1411$ & $-0,0698$ & $-6,9865$ \\
\hline 2,5784 & $-0,3824$ & $-0,1741$ & $-17,413$ \\
\hline 3,9705 & $-0,598$ & $-0,1773$ & $-17,731$ \\
\hline 4,3882 & $-0,3098$ & $-0,0759$ & $-7,5961$ \\
\hline 4,6666 & 0 & 0 & 0 \\
\hline
\end{tabular}

Figure 2 shows the results obtained by relations 2 and 3 compared to the laboratory determinations.

An error in viscosity calculation of up to $17 \%$ is observed. 
Table 6. Viscosity determined with the statistical relationship 3

\begin{tabular}{|c|c|c|c|}
\hline $\begin{array}{c}\text { Viscosity } \\
\text { determined }\left({ }^{\circ} \mathrm{E}\right)\end{array}$ & $\begin{array}{c}\text { Absolute error } \\
\text { (viscosity } \\
\text { measurement function } \\
\text { by viscosity } \\
\text { determined whit } \\
\text { relationship 3) }\end{array}$ & $\begin{array}{c}\text { Relative error (\%), } \\
\text { (absolute error } \\
\text { function by viscosity } \\
\text { determined whit } \\
\text { relationship 3) }\end{array}$ & $\begin{array}{c}\text { Relative error with } \\
\text { percentage } \\
\text { BASHRA ratio, \% }\end{array}$ \\
\hline 1,7387 & 0,1436 & 0,0763 & 7,6315 \\
\hline 1,8697 & 0,0714 & 0,0368 & 3,6821 \\
\hline 2,0007 & 0,0189 & 0,0093 & 0,9362 \\
\hline 2,3937 & $-0,1976$ & $-0,0899$ & $-8,9988$ \\
\hline 3,7037 & $-0,3311$ & $-0,0981$ & $-9,8190$ \\
\hline 4,0967 & $-0,0182$ & $-0,0044$ & $-0,4479$ \\
\hline 4,3587 & 0,30796 & 0,0659 & 6,5992 \\
\hline
\end{tabular}

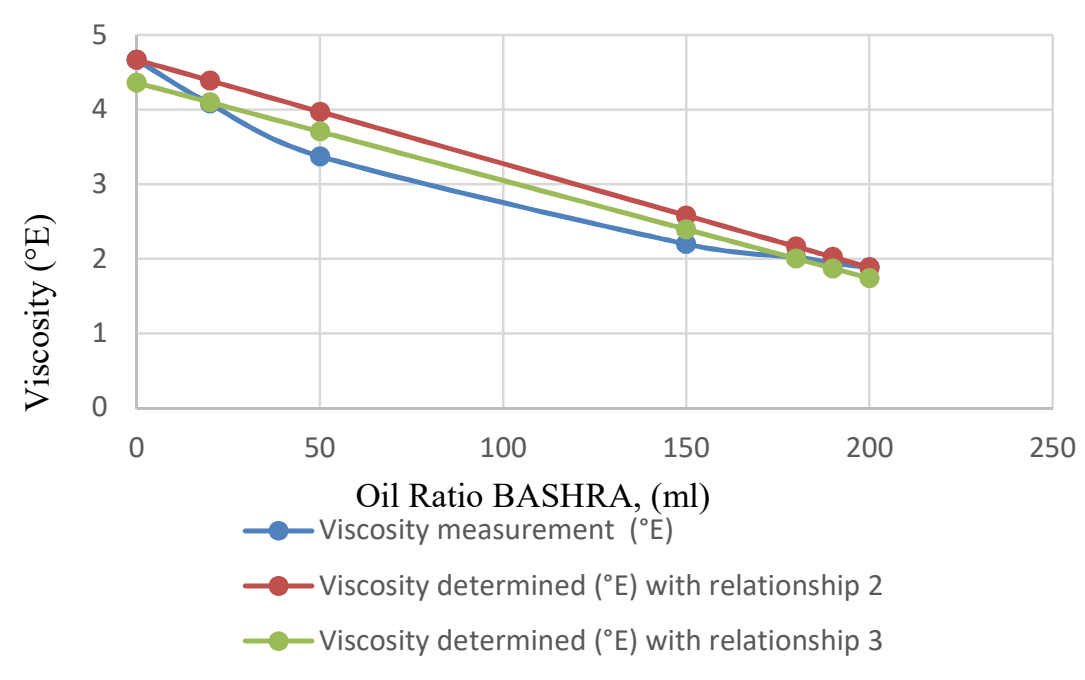

Figure 2. Mixture viscosity determined by physical analysis, as well as the calculation formula determined by percentage relationship (2) and numerical regression relationship (3)

Table 7.Viscosity determined and Henry Maurin Index viscosity, function by paper [3]

\begin{tabular}{|c|c|c|c|c|}
\hline $\begin{array}{c}\text { Oil ratio } \\
\text { BASHRA } \\
\text { ml, }\end{array}$ & $\begin{array}{c}\text { Oil ratio } \\
\text { PETROMAR } \\
\text { ml, }\end{array}$ & $\begin{array}{c}\text { Blend viscosity } \\
(\mathrm{s}) \text { measurement }\end{array}$ & $\begin{array}{c}\text { Viscosity } \\
\text { determined }\left({ }^{\circ} \mathrm{E}\right)\end{array}$ & $\begin{array}{c}\text { Henry Maurin } \\
\text { Index viscosity }\end{array}$ \\
\hline 200 & 0 & 96 & 1,8823 & 23,3800 \\
\hline 190 & 10 & 99 & 1,9411 & 23,6835 \\
\hline 180 & 20 & 103 & 2,0196 & 23,9870 \\
\hline 150 & 50 & 112 & 2,1960 & 24,8975 \\
\hline 50 & 150 & 172 & 3,3725 & 27,9325 \\
\hline 20 & 180 & 208 & 4,0784 & 28,8430 \\
\hline 0 & 200 & 238 & 4,6666 & 29,4500 \\
\hline
\end{tabular}


Table 8. Viscosity obtained by Henry Maurin Index [3]

\begin{tabular}{|c|c|c|c|}
\hline $\begin{array}{c}\text { Viscosity calculated } \\
\text { whit relationship 4 }\left({ }^{\circ} \mathrm{E}\right)\end{array}$ & $\begin{array}{c}\text { Absolute error } \\
\text { (viscosity } \\
\text { measurement } \\
\text { function by } \\
\text { viscosity } \\
\text { determined whit } \\
\text { relationship 4) }\end{array}$ & $\begin{array}{c}\text { Relative error } \\
\text { (viscosity } \\
\text { measurement } \\
\text { function by } \\
\text { viscosity } \\
\text { determined whit } \\
\text { relationship 4) }\end{array}$ & $\begin{array}{c}\text { Relative error } \\
\text { with percentage } \\
\text { BASHRA ratio, } \\
\%\end{array}$ \\
\hline 1,88 & 0,0023 & 0,0012 & 0,1249 \\
\hline 1,89 & 0,0511 & 0,0263 & 2,6363 \\
\hline 1,99 & 0,0296 & 0,0146 & 1,4660 \\
\hline 2,17 & 0,0260 & 0,0118 & 1,1874 \\
\hline 3,33 & 0,0425 & 0,0126 & 1,2616 \\
\hline 4,06 & 0,0184 & 0,0045 & 0,4519 \\
\hline 4,66 & 0,0066 & 0,0014 & 0,1428 \\
\hline
\end{tabular}

Table 9. Error relative to the oil mixture rate

\begin{tabular}{|c|c|c|c|}
\hline $\begin{array}{c}\text { Oil Ratio } \\
\text { BASHRA } \\
\text { ml, }\end{array}$ & $\begin{array}{c}\text { Error relative to } \\
\text { ratio of mixing } \\
\text { indices (4), } \\
\%\end{array}$ & $\begin{array}{c}\text { Error relative to } \\
\text { the statistical } \\
\text { relationship (3), } \\
\%\end{array}$ & $\begin{array}{c}\text { Error relative to } \\
\text { the relationship } \\
(2), \\
\%\end{array}$ \\
\hline 200 & 0,1249 & 7,6315 & 0 \\
\hline 190 & 2,6363 & 3,6821 & $-4,1414$ \\
\hline 180 & 1,4660 & 0,9362 & $-6,9902$ \\
\hline 150 & 1,1874 & $-8,9988$ & $-17,4107$ \\
\hline 50 & 1,2616 & $-9,8190$ & $-17,7325$ \\
\hline 20 & 0,4519 & $-0,4479$ & $-7,59615$ \\
\hline 0 & 0,1428 & 6,5992 & 0 \\
\hline
\end{tabular}

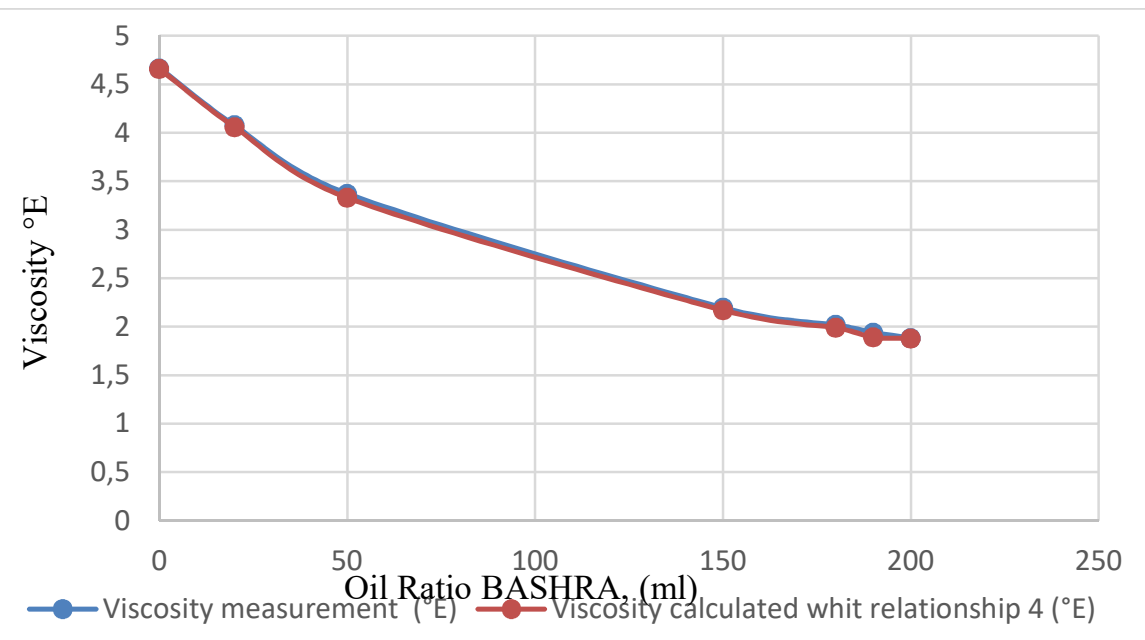

Figure 3. Viscosity of the mixture calculated with mixture indices relative to the determined viscosity $\left({ }^{\circ} \mathrm{E}\right)$ 
Figure 3 shows the results obtained by relation 4 to the laboratory determinations.

A viscosity calculation error of up to $2 \%$ is observed (Table 9 ).

\section{CONCLUSIONS}

By producing blends of crude oil, the following benefits can be gained:

a. Changes of the physical properties:

i. Density,

ii. Viscosity,

iii. Freezing point,

iv. Flow point.

b. Changes of the refinery products management:

i. Content of white products,

ii. Level of oil fuel.

c. Changes of the delivery price.

The process of creating crude oil mixtures is a trend that has become highly adopted in order to create recipes for refining, both from an economic perspective but also to ensure the creation of crude oil that offers the best result and has great characteristics for an existing installation.

It is easier to create a crude oil appropriate to the requirements of the designed installation than to modify the installation.

In order to ensure the successful sale of heavy crude oil, mixtures can be made as close as possible to the best and most expensive quality crude oil (Table, 3 , Table 4, Table 5, Table 6, Table 7, Table 8).

In order to determine the viscosity point of the mixture, the Henri Maurin Index can be successfully applied (with an error of up to 5\%) (Table 9),

The best technical mixing methodology consists in the in-line injection of the lightest mixture (in turbulent flow regime) with the control of the injection flow rates.

\section{REFERENCES}

[1] MINTON J. -Mitigation Strategies for Oil \& Chemical Cargoes Damaged by Contamination, Minton Treharne \& Davies Ltd., 2006, Propeler Ships Conference, 2008, pp.121-133.

[2] NICOLAU J.-Studii privind realizarea amestecurilor de țiței și produse petroliere, Raport intern, CHIMPEX CONSTANȚA, 1970.

[3] MAURIN H.-Programmation Lineaire Appliquee-Ed.Technip, Paris, 1967, pp.1280 .

[4] MANEA M., DUMITRU V., IONESCU V., BARBATU Gh.I.-Programarea matematică în industria petrolieră, Editura Academiei Republicii Socialiste România, București, 1970, pp.12-39. 
[5] CHIS T.- Modelling the chemical and physical properties of oil blend, $15^{\text {th }}$ International Scientific Conference, SGEM 2015, Varna, Bulgaria, 18-24 June 2015, Proceedings Conference ISSN 1314-2704, Vol.III, pp. 221-228.

[6] CHIS T.- Determination of the Optimal Mixtures of Romanian Crudes Oil for Processing, $12^{\text {th }}$ International Scientific Conference, SGEM 2012, Varna, Bulgaria, 1723 June 2012, Proceedings Conference ISSN 1314-2704, Vol.II, pp. 441-448;

[7] MARCU M.-Sensitivity Study of the Reservoir Fluids PVT Properties Calibration on Superficial Velocities and Liquid Holdup, Romanian Journal of Petroleum \& Gas Technology VOL. I (LXXII), No. 2/2020.

[8] LI X., YU W. - Modelling of Crude Oil Blending via Discrete-Time Neural Networks, World Academy of Science, Engineering and Technology, 2006, pp.300-340.

[9] LIANG, J. YONGHENG, H. DEXIAN, L. XIANGUANG-A Novel Scheduling Strategy for Crude Oil Blending, Chinese Journal of Chemical Engineering, pp.777-786 2010.

[10]. Standard Test Method for Engler Specific Viscosity of Tar Products, ASTM D1665 - 98 (2009).

[11] Standard Test Method for Density, Relative Density (Specific Gravity), or API Gravity of Crude Petroleum and Liquid Petroleum Products by Hydrometer Method, ASTM D1298-99, 2005. 